\title{
POETRY
}

\section{Soliloquy for a dying hero}

Sitting in a wheelchair, a baseball cap Pulled down over your eyes,

You rage and curse and shake your fist At hidden demons who bite your soul. While your other hand, with white-knuckled grip, Tries to strangle the unyielding armrest.

By chance, from a distance, we see you And pause in the malodorous hallway Of this nursing home, neat, cleanly painted With cheerful paintings lining the walls. We cannot help but stare;

Barely recognizing this ungodly transformation.

You were a man of consummate knowledge, Mercurial wit and masterful skill.

Oh revered doctor, how we ache to cure you! But know not how.

Sadly, you have gained tortured longevity, By way of genetics, fate and polypharmacy. Once more you rage and curse and shake your fist, While your mute, impassive attendant, Sole auditor of your bitter harangue, Slowly wheels you in the gloom.

\section{Barry Caplan MD}

Retired urologist

Winnipeg, Man.

CMAJ 2013. DOI:10.1503/cmaj.121667

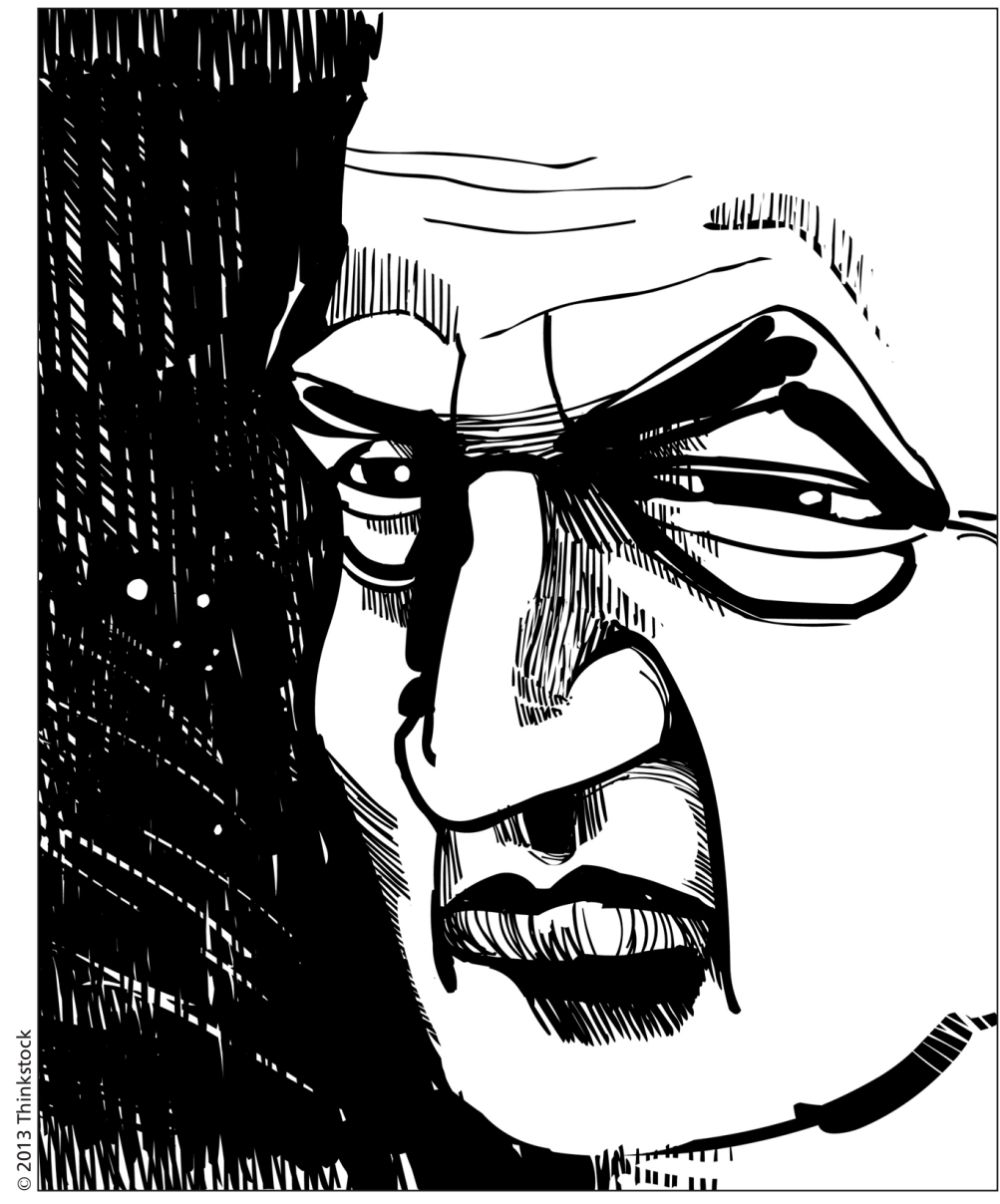

